\title{
Antiviral efficacy of favipiravir against canine distemper virus infection in vitro
}

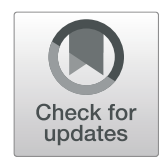

Xianghong Xue ${ }^{1,2+}$, Yelei Zhu ${ }^{1,3+}$, Lina Yan ${ }^{1 \dagger}$, Gary Wong ${ }^{4,5}$, Peilu Sun ${ }^{6}$, Xuexing Zheng ${ }^{1 *}$ and Xianzhu Xia ${ }^{7}$

\begin{abstract}
Background: Canine distemper (CD) is an acute infectious disease with high morbidity rates caused by a highly contagious pathogen (Canine Morbillivirus, also known as canine distemper virus, CDV). CDV can infect a broad range of carnivores resulting in complex clinical signs. Currently, there is no effective method to treat for CDV infections. Favipiravir (T-705), a pyrazine derivative, was shown to be an effective antiviral drug against RNA viruses, acting on RNA-dependent RNA polymerase (RdRp). However, whether the T-705 has antiviral effects following CDV infection is unclear. Here, we investigated the antiviral effect of T-705 against CDV-3 and CDV-11 strains in Vero and DH82 cell lines.

Results: Our data demonstrated that T-705 significantly inhibited the replication of CDV-3 and CDV-11 in both Vero and DH82 cells at different concentrations, ranging from $2.441 \mu \mathrm{g} / \mathrm{ml}$ to $1250 \mu \mathrm{g} / \mathrm{ml}$. Additionally, T-705 exhibited efficacious antiviral effects when administered at different time points after virus infection. Cytotoxicity tests showed a slight decline in viability in Vero cells after T-705 treatment, and no apparent cytotoxicity was detected in T-705 treated DH82 cells. Comparison of anti-CDV polyclonal serum only inhibition of CDV in supernatant, T-705 directly inhibited viral replication in cells, and indirectly reduced the amount of virions in supernatant. The combination application of T-705 and anti-CDV polyclonal serum exhibited a rapid and robust inhibition against virions in supernatant and virus replication in cells.
\end{abstract}

Conclusions: Our data strongly indicated that T-705 effectively inhibited viral replication following CDV infection in vitro, and could be a potential candidate for treatment for CD.

Keywords: Canine distemper, Canine distemper virus, Favipiravir, Antivirals

\section{Background}

Canine distemper virus (CDV), a member of the genus Morbillivirus within the family Paramyxoviridae, is a highly contagious pathogen that causes a multi-systemic disease with severe immunosuppression in carnivores $[1,2]$. CDV infects a broad range of animals, including the Canidae, Procyonidae, Felidae, Mustelidae, Mephitidae, Ailuridae, Viverridae, Hyaenidae and Phocidae [3, 4], causing complex clinical signs including respiratory, gastrointestinal and neurological symptoms. Pathogenic bacterial co-infections are known to complicate the clinical signs of CDV-infected animals [5]. Case-fatality rates of CDV infection ranged from 30 to $80 \%$ in most

\footnotetext{
* Correspondence: zhengxx2513@163.com

${ }^{+}$Xianghong Xue, Yelei Zhu and Lina Yan contributed equally to this work. 'Department of Virology, School of Public Health, Shandong University, Jinan 250012, China

Full list of author information is available at the end of the article
}

susceptible animals, and up to $100 \%$ in ferrets [6-9]. Recently, the natural hosts of CDV were widely expanded, even in non-human primates [6,10-12]. Rhesus monkeys were found to be naturally infected with CDV in Guangxi Province and Beijing, China, with mortality rates of 5 to $30 \%[6,10]$. Outbreaks in many endangered species, including the Amur tiger, Ethiopian wolf and giant panda, have also been reported [4, 13-15].

Currently, no antiviral drug has been approved for therapeutic application in wildlife animals against CDV infection. The routine vaccination against CDV has been widely conducted for many years. Modified live vaccines (MLV) have significantly reduced CDV infections in dogs and other carnivores [16]. However, MLV are not completely safe in highly susceptible species [17], and $\mathrm{CD}$ outbreaks are known to occur even in vaccinated animals [8].

(c) The Author(s). 2019 Open Access This article is distributed under the terms of the Creative Commons Attribution 4.0 International License (http://creativecommons.org/licenses/by/4.0/), which permits unrestricted use, distribution, and 
T-705 (favipiravir; 6-fluoro-3-hydroxy-2-pyrazine carboxamide), developed by Japan Toyama Chemical Industry Co., Ltd., is an antiviral agent with a primary mechanism of suppressing the RNA-dependent RNA polymerase (RdRP) activity. As a purine analog prodrug, T-705 converts to active form T-705 ribofuranosyl-5' triphosphate (T-705-RTP) in cells, which inhibits viral replication by preventing further extension of the RNA strands [18]. T-705 has been confirmed as an efficient inhibitor against a broad range of RNA viruses with RdRP in vitro and in vivo, such as influenza virus [18], Arena-[19], Bunya-[20, 21], Flavi-[22, 23], Ebola-[24], Noro-[25], and Paramyxoviridae [26]. However, the antiviral effect of T-705 on CDV has not yet been investigated.

The genome of CDV is a single-stranded negativesense RNA, which codes a RdRP protein with a binding domain of ATP and/or purine ribonucleotide triphosphate $[27,28]$. Based on the efficacy of T-705 against RNA viruses in previous studies, our presumption is that T-705 may also work on CDV. Thus, in this study, we investigated the inhibitory effect of T-705 against two different CDV strains in Vero and DH82 cells, and compared the inhibitory effects of T-705 with an anti-CDV polyclonal serum. Our findings indicated that T-705 could be a potential anti-CDV drug.

\section{Results}

\section{Growth characteristics of CDV-3 and CDV-11 in Vero and DH82 cells}

The growth characteristics of CDV-3 and CDV-11 strains in Vero and DH82 cells were determined by indirect immunofluorescence assay (IFA). Both Vero and DH82 cell lines inoculated with CDV-3 or CDV-11, exhibited a strongly positive reaction signal with anti-CDV $\mathrm{N}$ monoclonal antibody (Fig. 1c-f); in contrast, no positive reaction signal with anti-CDV $\mathrm{N}$ monoclonal antibody was observed in mock cells (Fig. 1a and b. In addition, 50\% tissue culture infectious dose per milliliter assay $\left(\mathrm{TCID}_{50}\right)$ was used to determine the viral titers of cultured viruses at different time points (Fig. 1g). In Vero cells, viral titers of CDV-3 and CDV-11 peaked at $10^{5.5}$ and $10^{6.6} \mathrm{TCID}_{50} / \mathrm{ml}$ at $72 \mathrm{~h}$, respectively, and maintained a plateau between $72 \mathrm{~h}$ and $96 \mathrm{~h}$. In DH82 cells, CDV exhibited a continuous increase of viral titers in the tested range of time points, and viral titers of CDV-3 and CDV-11 both peaked approximately at $10^{5.5}$ $\mathrm{TCID}_{50} / \mathrm{ml}$ at $96 \mathrm{~h}$.

\section{Cytotoxicity of T-705}

The CCK-8 method was performed on Vero and DH82 cells to determine the cytotoxic levels of T-705 (Fig. 2). A slight decline of viability of Vero cells treated with $\mathrm{T}$ 705 was observed at concentrations of $625 \mu \mathrm{g} / \mathrm{ml}$ and
$1250 \mu \mathrm{g} / \mathrm{ml}$. No obvious cytotoxicity was observed in T705 treated DH82 cells for all tested drug concentrations. Moreover, the $\mathrm{CC}_{50}$ (50\% cytotoxic concentration) values of T-705 in both cell lines were estimated to be higher than $1250 \mu \mathrm{g} / \mathrm{ml}$.

\section{Inhibitory effects of T-705 on replication of CDV in Vero and $\mathrm{DH} 82$ cell lines}

To investigate whether $\mathrm{T}-705$ could inhibit replication of CDV, the antiviral effect of T-705 against CDV-3 and CDV-11 strains was evaluated in both Vero and DH82 cells (Fig. 3). The T-705 was simultaneously added with CDV strains to both cell lines. T-705 significantly reduced viral titers in both cell lines by a dose-dependent manner. Complete suppression of viral replication by approximately 5 or 6 logs was observed with T-705 at concentration levels of $78.125 \mu \mathrm{g} / \mathrm{ml}$ in CDV-11-infected Vero cells, $156.25 \mu \mathrm{g} / \mathrm{ml}$ in CDV-11-infected DH82 cells, and CDV-3-infected Vero and DH82 cells.

To assess the antiviral effects of T-705 against CDV, the half maximal inhibitory concentration $\left(\mathrm{IC}_{50}\right)$ of $\mathrm{T}$ 705 against CDV was determined (Table 1). The values of $\mathrm{IC}_{50}$ for CDV-3-Vero, CDV-11-Vero, CDV-3-DH82 and CDV-11-DH82 were $25.2 \mu \mathrm{g} / \mathrm{ml} \quad(151.2 \mu \mathrm{M})$, $7.05 \mu \mathrm{g} / \mathrm{ml} \quad(42.3 \mu \mathrm{M}), \quad 33.54 \mu \mathrm{g} / \mathrm{ml} \quad(201.24 \mu \mathrm{M})$ and $16.97 \mu \mathrm{g} / \mathrm{ml}(101 \mu \mathrm{M})$, respectively, with selectivity indexes (SI) of higher than 49.6, 177.3 in Vero cells and higher than 37.27 and 73.66 in DH82 cells. Our results indicated that $\mathrm{T}-705$ could significantly inhibit the replication of CDV-3 and CDV-11 in Vero and DH82 cells within the tested range.

\section{T-705 moment-of-addition experiment}

Moment-of-addition experiments were performed to determine whether T-705 had effective and stable antiviral capacity in CDV-infected Vero and DH82 cells at different moments of drug additions. Inhibition percentages of T-705 were not as $100 \%$ as added immediately at $0 \mathrm{~h}$, but still more than $30 \%$ in late moment of additions at $12 \mathrm{~h}$ to $48 \mathrm{~h}$ p.i.. In comparison of the mock-treated but virus-infected cells, viral titers were significantly reduced by 1000 times, when $\mathrm{T}-705$ was added at $12 \mathrm{~h}$ to $48 \mathrm{~h}$ after viral infection (Fig. 4). Therefore, the T-705 has a strong inhibitory effect on CDV replication when added at 12, 24, 36 or $48 \mathrm{~h}$ p.i.. However, in this case, at the same moments of addition of the T-705, different concentrations did not significantly affect the virus titers, and the antiviral activity was similar in all tested concentrations of drug (Fig. 4 e-h). These data indicated that even late intervention of CDV-infected cells with small concentrations of T-705 is still significantly effective. 


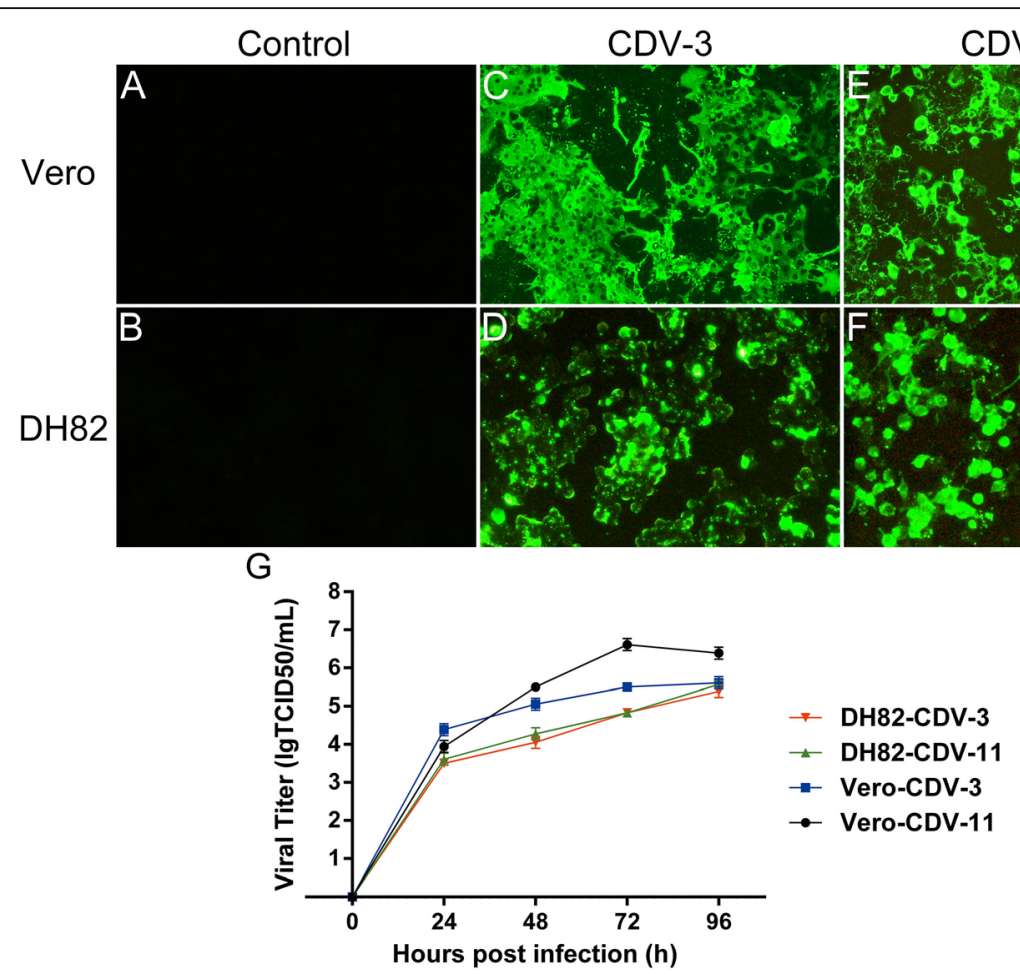

Fig. 1 Growth characteristics of CDV-3 and CDV-11 in Vero and DH82 cells. Vero cells were infected with CDV-3 (c) and CDV-11 (e) at a MOI of 0.1 , DH82 cells were infected with CDV-3 (d) and CDV-11 (f) at a MOI of 0.1, Vero (a) and DH82 cells (b) with no CDV infection were served as controls. Cells were incubated for 3 days and then fixed and stained with CDV monoclonal antibody specific for nucleoprotein. (Magnification, $\times$ 200) (g) Growth curves of CDV were performed in Vero and DH82 cells. Cells were infected with CDV-3 or CDV-11 at a MOI of 0.1 and incubated at $37^{\circ} \mathrm{C}$. Viruses were collected at $0,24,48,72$, and $96 \mathrm{~h}$ p.i. and viral titers tested as described in Materials and Methods. Experiments were both carried out in triplicate

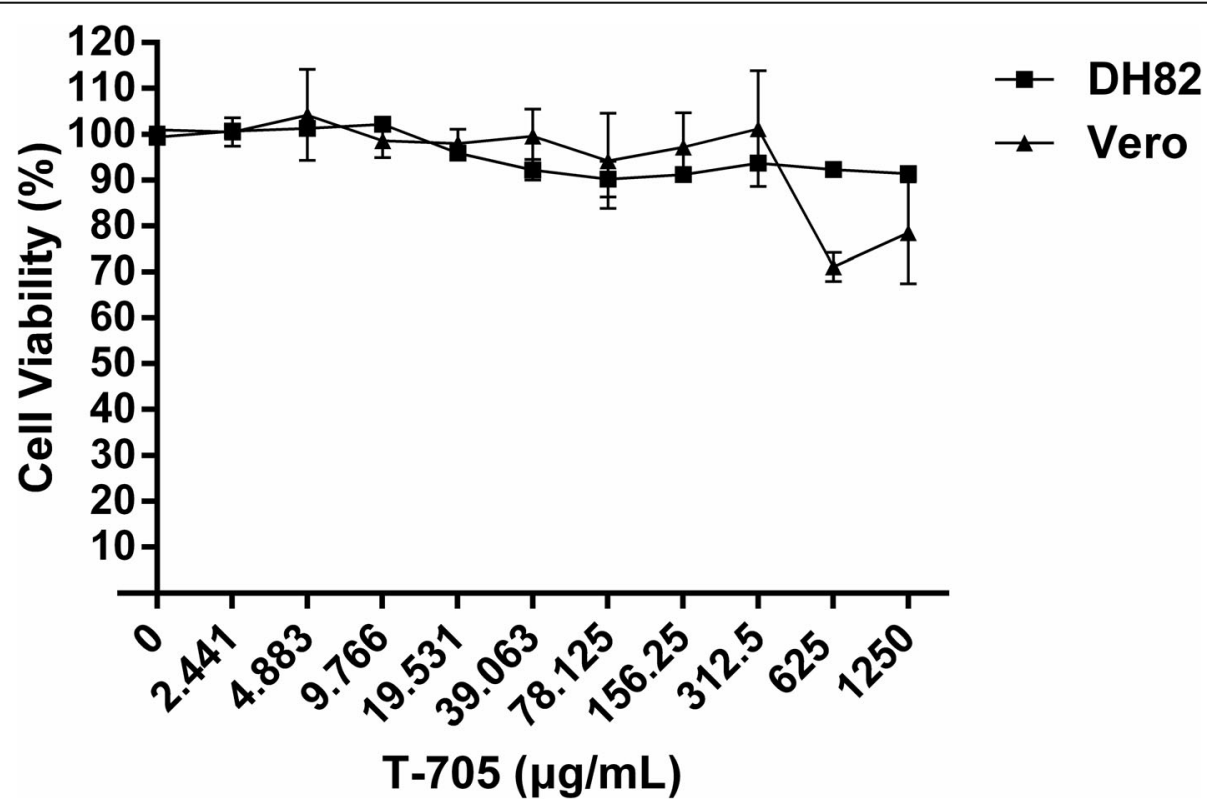

Fig. 2 Cytotoxicity test of T-705 in Vero and DH82 cells. Different concentrations of T-705 were added in Vero and DH82 cells. After incubation at $37^{\circ} \mathrm{C}$ for $96 \mathrm{~h}$, CCK-8 was added and incubated for $2 \mathrm{~h}$ to determine the absorbance at $450 \mathrm{~nm}$. Cells with no drugs were served as controls. Cell viability was measured by comparing the drug-treated cells with controls. Both experiments were carried out in triplicate 

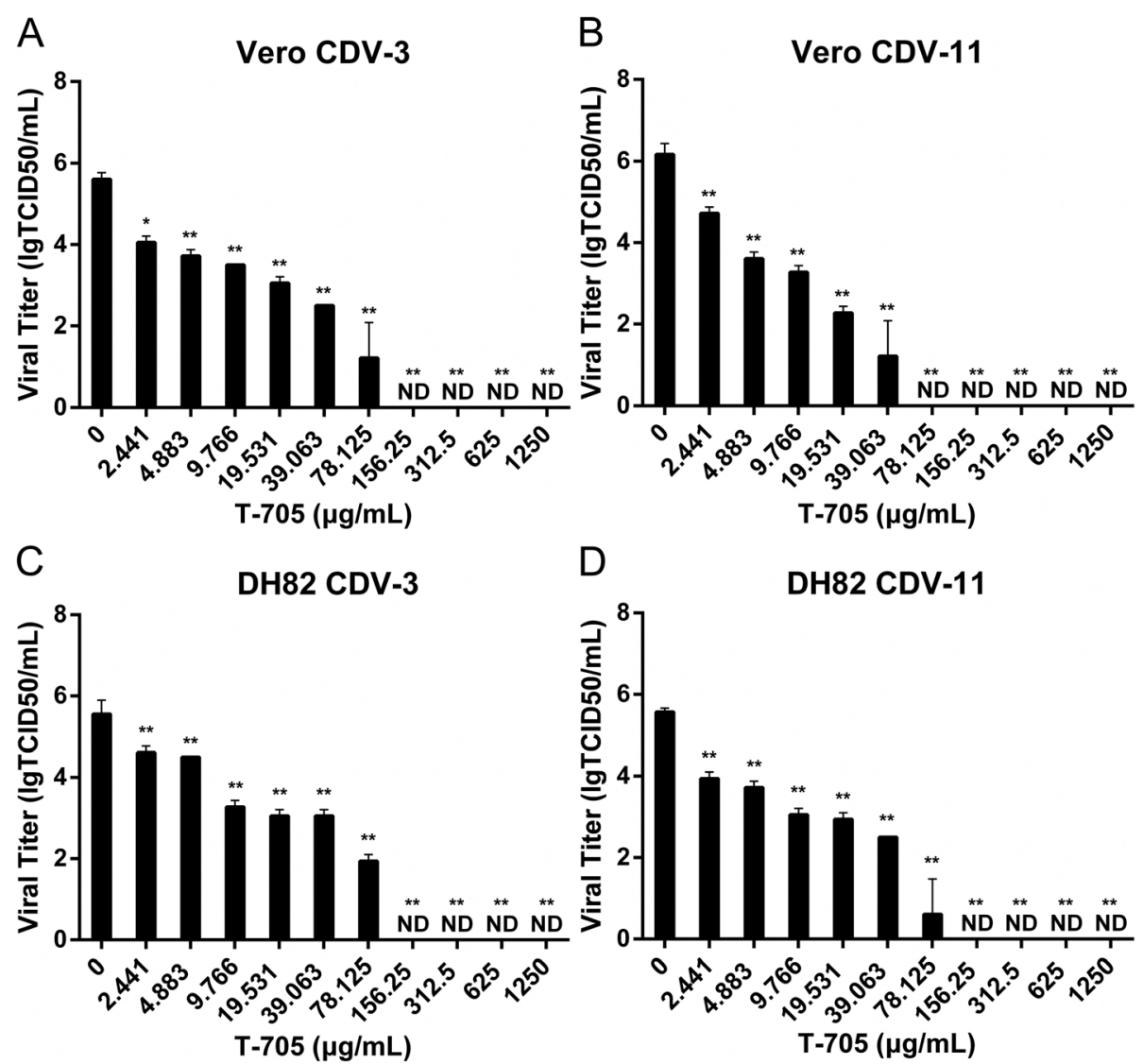

Fig. 3 Inhibition of CDV by T-705 in two cell lines. Vero and DH82 cells were infected with CDV-3 (a and $\mathbf{c}$ ) and CDV-11 (b and $\mathbf{d})$ at a MOI of 0.1. Cells were exposed to different compound concentrations at the same time. Cells and the culture medium were collected at $96 \mathrm{~h}$ p.i. for virus titration. Cells with no drugs were served as controls. Experiments were carried out in triplicate. Statistical significance was analyzed by one-way ANOVA (Dunnett's t-test). ${ }^{*}, P<0.01 ;{ }^{* *}, P<0.0001$. ND means non-detectable

\section{Comparison of antiviral effects between T-705 and} anti-CDV polyclonal serum alone or in combination To evaluate the inhibition ability of T-705, we compared the antiviral effects of T-705, anti-CDV polyclonal serum, and a combination of T-705 and antiCDV polyclonal serum. As shown in Fig. 5a, c, e, g, among the indicated time points, the anti-CDV polyclonal serum had little antiviral efficacy against CDV3 or CDV-11 in both cells after $36 \mathrm{~h}$ p.i., while T-705 showed robust antiviral effects in both cells between 0 and $48 \mathrm{~h}$ p.i.. As shown in Fig. 5b, d, f, h, viral titers of both CDV strains in supernatant declined to
0 when CDV-infected Vero or DH82 cells were treated with anti-CDV polyclonal serum or a combination of T-705 and anti-CDV polyclonal serum at 0 , 12 and $24 \mathrm{~h}$, while T-705 group showed less significantly hinderance to virions in supernatant. Briefly, anti-CDV polyclonal serum showed a perfect inhibitory effect against CDV virions in supernatant rather than inhibiting viral replication. T-705 exhibited robust antiviral effect in cells where converted to active form. Thus, T-705 combined with anti-CDV polyclonal serum showed an excellent inhibitory effect in supernatant and cells at $48 \mathrm{~h}$ p.i. of both CDV strains.

Table 1 Inhibitory effects of T-705 against CDV replication in different cell lines

\begin{tabular}{|c|c|c|c|c|c|c|}
\hline \multirow[t]{2}{*}{ Virus } & \multicolumn{2}{|c|}{$\mathrm{CC}_{50} \pm \mathrm{SD}(\mu \mathrm{g} / \mathrm{ml})^{\mathrm{a}}$} & \multicolumn{2}{|c|}{$\mathrm{IC}_{50} \pm S D(\mu \mathrm{g} / \mathrm{ml})^{\mathrm{a}}$} & \multicolumn{2}{|l|}{$\mathrm{SI}^{\mathrm{b}}$} \\
\hline & Vero & DH82 & Vero & $\mathrm{DH} 82$ & Vero & $\mathrm{DH} 82$ \\
\hline CDV-3 & $>1250$ & $>1250$ & $25.20 \pm 2.69$ & $33.54 \pm 1.20$ & $>49.60$ & $>37.27$ \\
\hline CDV-11 & $>1250$ & $>1250$ & $7.05 \pm 1.87$ & $16.97 \pm 3.35$ & $>177.30$ & $>73.66$ \\
\hline
\end{tabular}

${ }^{\mathrm{a}}$ Determined from 3 independent experiments

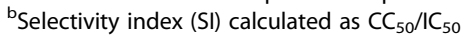




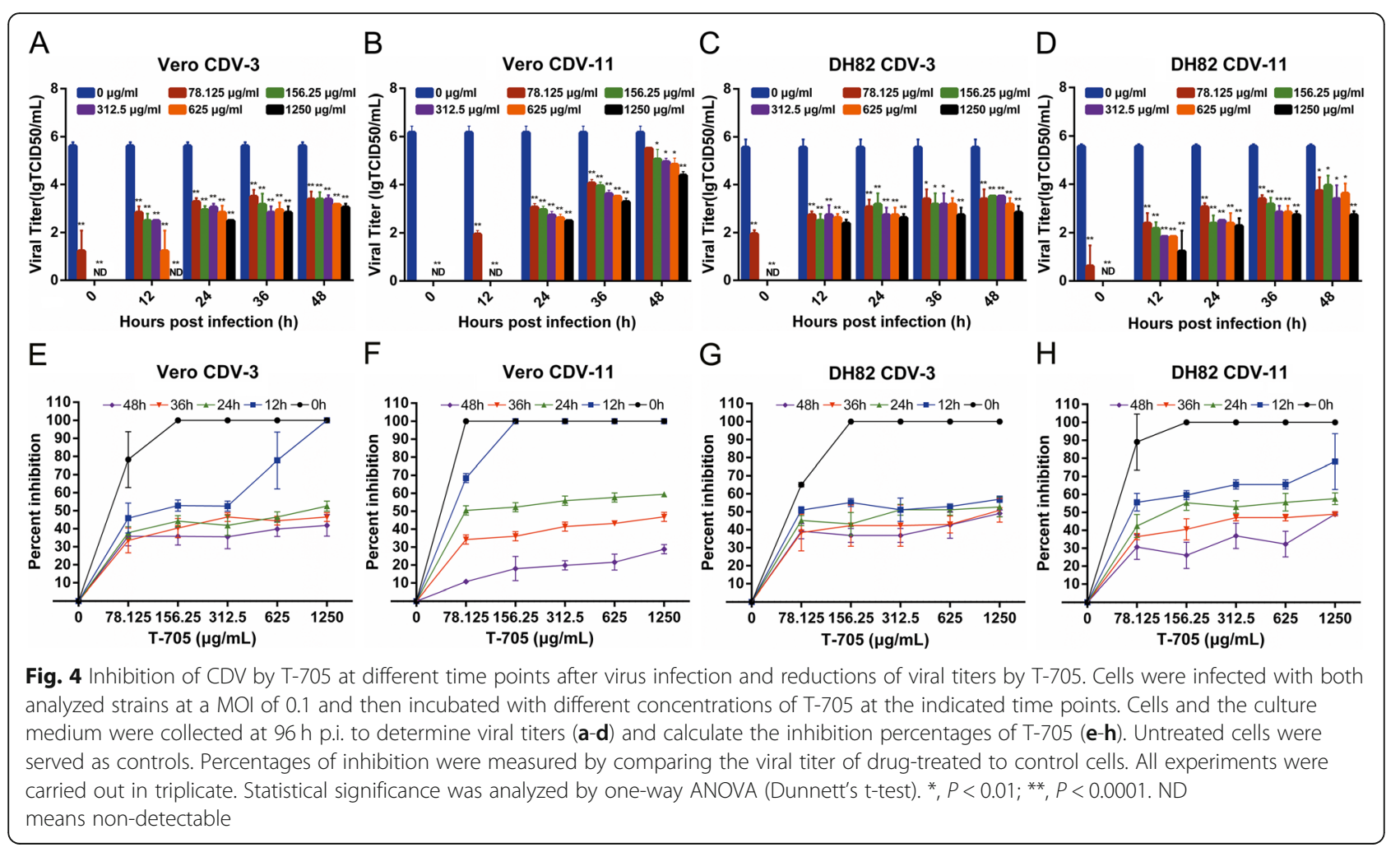

\section{Discussion}

The routine vaccination against CDV MLV has been widely conducted for many years. However, MLV might cause severe diseases and deaths in highly susceptible species [17]. There were many cases of canine distemper outbreaks in vaccinated animals $[8,29]$. Cases of dogs suffering encephalitis after vaccination [29] have been reported in young dogs, and the immunity failure is mainly caused by inadequate immune responses to MLV with the presence of maternal antibody in puppy [30,31]. In addition, whether the MLV is suitable to the endangered species, needs to be considered for the variants with different susceptibilities among wild animals [32]. To address this problem, researchers investigated many antiviral drugs against CDV in vitro. Carvalho et al assessed the antiviral activity of several flavonoids and phenolic acids added at different time points [33]. Lanave et al assessed the antiviral efficacy of ribavirin and boceprevir alone or in combination against CDV [34]. Other studies showed that caffeic acid has significant anti-CDV effect in Vero cells [35]. María de Jesús González-Búrquez et al demonstrated the antiviral activity of the ethanolic extract of Mexican propolis, as well as the synergistic effect that exists between both studied favonoids [36]. Additionally, Krumm et al showed that treatment of CDV-infected ferrets, with an inhibitor which targeted the viral polymerase, could reduce viremia and prolong survival [37]. Other therapeutics including neutralizing monoclonal antibodies against the CDV hemagglutinin protein and nucleocapsid protein $[38,39]$ showed potential immunotherapy against CDV infection in dogs. However, the polyclonal serum has disadvantages of limited sources and heterologous reactions, which restricted its clinical application, especially in wildlife and the endangered species.

There is no effective antiviral molecular currently available to treat for CDV infection in susceptive animals. Thus, T-705, as a confirmed property, inhibits replication of a broad range of RNA viruses both in vitro and in vivo. Here, we have extended the spectrum of T705 , demonstrating robust antiviral activity against CDV in vitro. Our results in this work indicated that T-705 effectively suppressed CDV-3 and CDV-11 in Vero and DH82 cells. In Vero cells, the $\mathrm{IC}_{50}$ of $\mathrm{T}-705$ against CDV was $25.2 \mu \mathrm{g} / \mathrm{ml}$ for CDV-3 and $7.05 \mu \mathrm{g} / \mathrm{ml}$ for CDV-11. In DH82 cells, the $\mathrm{IC}_{50}$ of $\mathrm{T}-705$ against CDV was $33.54 \mu \mathrm{g} / \mathrm{ml}$ for CDV-3 and $16.97 \mu \mathrm{g} / \mathrm{ml}$ for CDV11. These findings were comparable to those reported for other RNA viruses, including West Nile virus $\left(\mathrm{IC}_{50}: 53 \mu \mathrm{g} / \mathrm{ml}\right.$ ) [40], foot-and-mouth disease virus $\left(\mathrm{IC}_{50}: 14 \mu \mathrm{g} / \mathrm{ml}\right)$ [41], Ebolavirus $\left(\mathrm{IC}_{50}: 10.5 \mu \mathrm{g} / \mathrm{ml}\right)$ [24], murine norovirus $\left(\mathrm{IC}_{50}: 39 \mu \mathrm{g} / \mathrm{ml}\right)$ [25] and Zika virus $\left(\mathrm{IC}_{50}: 17.4 \mu \mathrm{g} / \mathrm{ml}\right)$ [42]. D. Jochmans et al demonstrated that recombinant MeV-Edm-GFP was the most sensitive to T-705 treatment of all tested paramyxoviruses, with $90 \%$ effective concentration $\left(\mathrm{EC}_{90}\right)$ values of $8.6 \mu \mathrm{M}(1.7 \mu \mathrm{g} / \mathrm{ml}), 9.7 \mu \mathrm{M}(1.9 \mu \mathrm{g} / \mathrm{ml})$, and 

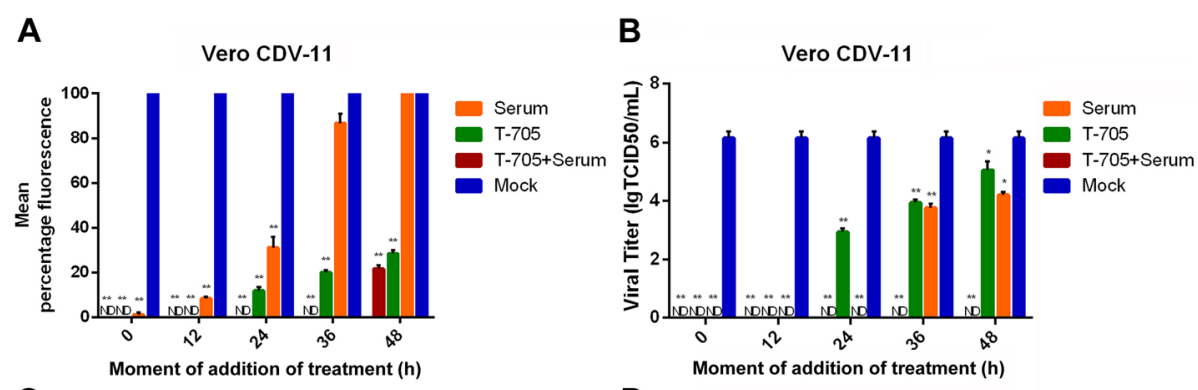

C

DH82 CDV-11

D

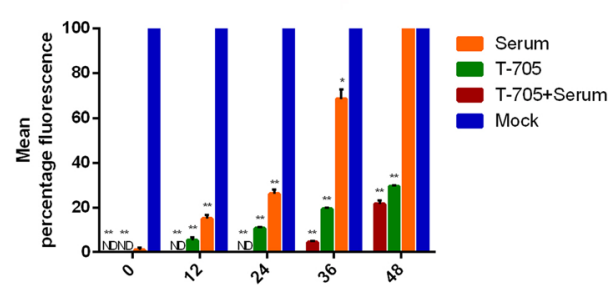

E

Moment of addition of treatment (h)

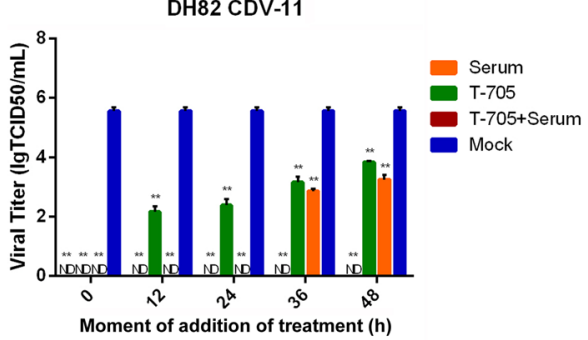

F

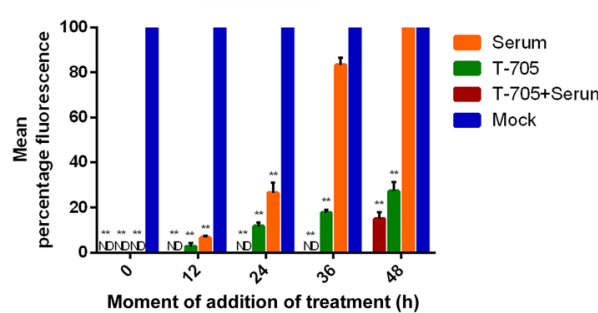

G

DH82 CDV-3

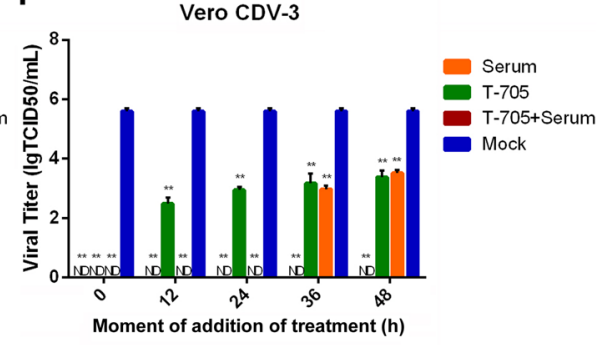

H

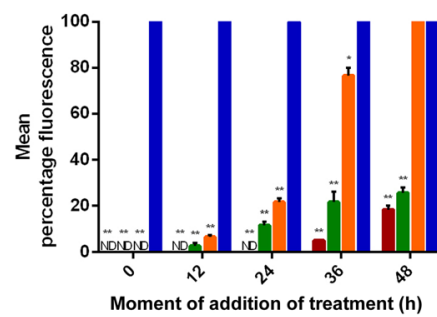

DH82 CDV-3

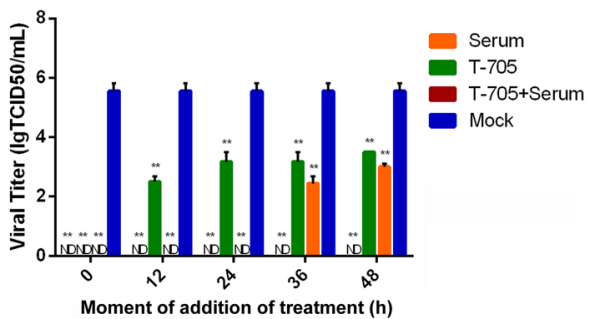

Fig. 5 Comparisons of antiviral effects of T-705 and anti-CDV polyclonal serum. The Vero and DH82 cells were treated with T-705 (156.25 $\mu \mathrm{g} / \mathrm{ml})$, anti-CDV polyclonal serum (1:128) and a combination of T-705 $(156.25 \mu \mathrm{g} / \mathrm{ml})$ and anti-CDV polyclonal serum $(1: 128)$ at $0,12,24,36$ and $48 \mathrm{~h}$ p.i. with CDV-3 and CDV-11 at a MOI of 0.1. The mock groups were treated with DMEM p.i. at the same times. The virus titers in supernatant $(\mathbf{b}, \mathbf{d}, \mathbf{f}, \mathbf{h})$ were determined and compared with the viral titers in mock group. Viral replications in cells were detected by IFA and the mean fluorescence percentages $(\mathbf{a}, \mathbf{c}, \mathbf{e}, \mathbf{g})$ were calculated as the average of fluorescent areas under twenty randomly selected fields. All experiments were carried out in triplicate. Statistical significance was analyzed by one-way ANOVA (Dunnett's t-test). ${ }^{*}, P<0.01 ;{ }^{* *}, P<0.0001$

$13 \mu \mathrm{M}(2.56 \mu \mathrm{g} / \mathrm{ml})$ for treatment prior to, simultaneous with, and after inoculation [26]. During CDV infection, viral particles are likely to directly attack the peripheral blood mononuclear, macrophages and other immune cells in hosts, and then transmit to bronchial lymph nodes and tonsils within the first $24 \mathrm{~h}$ p.i. [43-45]. Finally, it induces a long-term immunosuppression. In this study, T-705 showed robust antiviral effects against CDV in DH82 cells, a cell line from canine macrophages, which suggested that $\mathrm{T}-705$ may be promising as a post-exposure therapeutic drug for CDV infection.
The moment-of-addition experiments proved that $\mathrm{T}$ 705 had significant antiviral effects against both CDV strains with addition between 0 and $48 \mathrm{~h}$ after virus infection in both cell lines. In previous studies, T-705 was shown to be phosphoribosylated to T-705RTP in cells by intracellular enzymes and then recognized as a purine analog by viral $\mathrm{RdRp}$ to inhibit viral replication $[26,46]$. That explained why a period of time was needed to reach an effective drug concentration. Virus titers of CDV exhibited a stable decline in DH82 and Vero cells, reaching roughly $10^{3.5}$ or $10^{4} \mathrm{TCID}_{50} / \mathrm{ml}$ at $48 \mathrm{~h}$ after 
addition of T-705, in both cell lines, respectively. T-705 still exhibited a more than $30 \%$ inhibition rate on replications of CDV-3 or CDV-11 in Vero and DH82 cells even when added at $48 \mathrm{~h}$ after virus infection. The antiviral effects of T-705 against CDV showed concentration dependence and negative correlation with additional time. Previous studies demonstrated that the intervention effect of T-705 appeared at an early and intermediate stage of virus replication. In influenza virus, T-705 showed no effect when added at 6 to $10 \mathrm{~h}$ after infection [47]. In Tacaribe virus and Junín virus, there was little or no antiviral effect when T-705 was added at $18 \mathrm{~h}$ after virus infection [19]. Therefore, it is suspected that T-705 is more effective in combatting CDV infections as a post-exposure treatment. T-705 must have enough time to enter cells and switch to active form, before its antiviral effects exhibit. Comparisons of inhibitory effects between T-705 and anti-CDV polyclonal serum, showed that anti-CDV polyclonal serum only inhibited CDV in supernatant, while T-705 had little hinderance against CDV in supernatant directly. However, T-705 indirectly lessened virions concentration in supernatant by inhibiting viral replication in cells. T-705 combined with antiCDV polyclonal serum showed an excellent and significant inhibitory effect in both supernatant and cells. Practical applicability of anti-CDV polyclonal serum was restricted by species specificity, but T-705 has a broad spectrum as an antiviral drug. The antiviral effect of $\mathrm{T}$ 705 against $C D V$ in vivo was partially restricted for different susceptibility and pathogenicity of CDV in different animal models [48]. Our in vitro results indicated that T-705 was promising as a post-exposure treatment, and the antiviral effect of T-705 in vivo will be evaluated in a future study.

\section{Conclusions}

In this study, our findings demonstrated that T-705 could effectively suppress viral replication in CDV infected Vero and DH82 cells, indicating strong potential of T-705 as a treatment of CDV infections in the future.

\section{Methods}

\section{Compound, viruses, cells and serum}

T-705 (CAS No. 259793-96-9) was purchased from MCE, dissolved in DMEM at a concentration of $5 \mathrm{mg} / \mathrm{ml}$ $(30 \mathrm{mM})$, stored at $4{ }^{\circ} \mathrm{C}$ and used within 1 week. DH82 cells (ATCC-CRL-10389), a continuous cell line from canine macrophage, and Vero cells (ATCC-81), were both cultured in Dulbecco's Modified Eagle Medium (DMEM), (Gibco, China) with $10 \%(\mathrm{v} / \mathrm{v})$ fetal bovine serum (FBS), (Gibco, Australia). CDV-3 was gifted from JiLin Teyan Pharmaceutical Co. Ltd., and CDV-11 was gifted from QiLu Animal Health Products Co. Ltd. Both strains were propagated in Vero and DH82 cells in $2 \%$
FBS supplied DMEM, and titrated by $50 \%$ endpoint titration. Anti-CDV polyclonal serum was purchased from Changchun Sino Biological Technology Co. Ltd.,

\section{Cell viability}

Viability of Vero and DH82 cells was performed using the Cell Counting Kit-8 (CCK-8, Dojindo, Japan). Briefly, Vero or DH82 cells at $80-90 \%$ confluence were grown in a medium containing different concentrations of $\mathrm{T}$ 705 in 96 -well plates. After incubation at $37^{\circ} \mathrm{C}$ for $96 \mathrm{~h}$, $10 \mu \mathrm{l}$ of CCK-8 solution was added and incubated for a further $2 \mathrm{~h}$ at $37^{\circ} \mathrm{C}$. The absorbance at $450 \mathrm{~nm}$ was determined. The cell viability was measured by comparing T-705-treated and mock-treated cells. This experiment was carried out in triplication.

\section{Virus titration}

The viral titers of both strains were determined by $50 \%$ endpoint titration in Vero cells and expressed as $\mathrm{TCID}_{50} / \mathrm{ml}$. Vero cells in 96-well plates were combined with serial 10-fold dilutions of the virus, and incubated for $72 \mathrm{~h}$ at $37{ }^{\circ} \mathrm{C}$. Cells were fixed with $80 \%$ ice-cold acetone. Virus concentrations were measured by IFA. Cells were stained with CDV monoclonal antibody specific to nucleoprotein (VMRD, USA) and Alexa Fluor 488-conjugated Affinipure Goat Anti-Mouse $\operatorname{IgG}(\mathrm{H}+\mathrm{L})$ (Proteintech, China). The cells were examined by fluorescent microscopy. Mock treated cells were used as a negative control. This experiment was carried out in triplication.

\section{Viral inhibition assay}

To determine the effect of T-705 against CDV in vitro, the culture medium of Vero or DH82 cells infected with CDV-3 or CDV-11 at a MOI of 0.1 , were replaced by a medium containing T-705 $(0,78.125,156.25,312.5,625$, or $1250 \mu \mathrm{g} / \mathrm{ml})(0,468,937,1875,3750,7500,15$, $000 \mu \mathrm{M})$ at the indicated time points. As for time course experiments, five different time points $(0 \mathrm{~h}, 12 \mathrm{~h}, 24 \mathrm{~h}$, $36 \mathrm{~h}$ and $48 \mathrm{~h}$ post infection (p.i.)) were set to investigate whether T-705 could still show effective and stable antiviral activity during late administration of drug. In both cases, at $96 \mathrm{~h}$ p.i., cells and the culture medium were collected by freezing and thawing three times, and viral titers were measured by IFA as described previously. This experiment was carried out in triplication.

\section{Comparison of antiviral effects of T-705 and anti-CDV polyclonal serum}

The titer of virus neutralizing antibody (VNA) of antiCDV polyclonal serum was 1:1024. A $250 \mu$ l of antiCDV polyclonal serum was diluted in a $2 \mathrm{ml}$ of DMEM, and the mixture has a final VNA titer of 1:128. The 
diluted polyclonal sera were tested for inhibition effects in a 6-well plate.

To evaluate the inhibitory effects of T-705 and antiCDV polyclonal serum, the CDV-3 or CDV-11-infected Vero and DH82 cells were added with T-705 $(156.25 \mu \mathrm{g} / \mathrm{ml})$, anti-CDV polyclonal serum (1:128) and a combination of T-705 $(156.25 \mu \mathrm{g} / \mathrm{ml})$ and antiCDV polyclonal serum (1:128) at $0,12,24,36$ and $48 \mathrm{~h}$, respectively. The mock group was treated with $2 \%$ FBS DMEM after infection with CDV-3 or CDV-11. Viral titers in supernatant and viral replication of CDV in cells were determined by IFA at $96 \mathrm{~h}$ p.i.. Antiviral effects of tested groups were compared with mock groups treated with $2 \%$ FBS DMEM of CDV-infected cells. This experiment was carried out in triplication.

\section{Statistical analysis}

The data were displayed as the mean \pm standard deviation (SD). Differences among viral titers were analyzed using GraphPad Prism 6 by one-way ANOVA (Dunnett's t-test). Statistical significance was considered at $* P<0.01$ and $* * 000001$.

\section{Abbreviations \\ $\mathrm{CC}_{50}$ : $50 \%$ cytotoxic concentration; CDV: Canine distemper virus; DMEM: Dulbecco's modified eagle medium; $\boldsymbol{I}_{50}$ : the half maximal inhibitory concentration; IFA: Immunofluorescence assay; MLV: Modified live vaccines; MOI: Multiply of infection; p.i: post infection; RdRP: RNA-dependent RNA polymerase; SI: Selectivity index; T-705: favipiravir; T-705-RTP: T-705- ribofuranosyl-5'-triphosphate; $\mathrm{TCID}_{50}$ : 50\% tissue culture infectious dose; VNA: Virus neutralizing antibody}

\section{Acknowledgements}

We gratefully acknowledge the infrastructure support of the college of public health in Shandong University.

\section{Authors' contributions}

XX Z designed this study; XH X drafted the manuscript; YL Z and LN Y completed tests and the acquisition of data collected the data; PL $S$ analyzed the data; G W edited the manuscript; XZ X aided in interpretation of data. All authors read and approved the final manuscript.

\section{Funding}

This work was supported by The National Key Research and Development Program of China (2016YFD0501003, 2017YFD0501804), Shandong Provincial Natural Science Foundation (ZR2016CQ18) and the China Postdoctoral Science Foundation funded project (2015 M580592, 2016 T90637). The funding body designed the whole program.

\section{Availability of data and materials}

The data used and/or analyzed during the current study available from the corresponding author on reasonable request.

\section{Ethics approval and consent to participate}

Not applicable.

\section{Consent for publication}

Not applicable.

\section{Competing interests}

The authors declare that they have no competing interests.

\section{Author details}

'Department of Virology, School of Public Health, Shandong University, Jinan 250012, China. ${ }^{2}$ Division of Infectious Diseases of Special Animal, Institute of Special Animal and Plant Sciences, The Chinese Academy of Agricultural Sciences, Changchun 130112, China. ${ }^{3}$ Zhejiang Provincial Center for Disease Control and Prevention, Hangzhou 310051, China. ${ }^{4}$ Institute Pasteur of Shanghai, Chinese Academy of Sciences, Shanghai 200031, China.

${ }^{5}$ Département de microbiologie-infectiologie et d'immunologie, Université Laval, QC, Québec G1V 4G2, Canada. Institute of Materia Medical, Shandong Academy of Medical Sciences, Jinan 250062, China. Institute of Military Veterinary, Academy of Military Medical Sciences, Changchun 130122, China.

Received: 26 March 2019 Accepted: 21 August 2019

Published online: 02 September 2019

\section{References}

1. Pillet $\mathrm{S}$, Messling W. Canine distemper virus selectively inhibits apoptosis progression in infected immune cells. J Virol. 2009;83(12):6279.

2. Pratakpiriya W, Seki F, Otsuki N, Sakai K, Fukuhara H, Katamoto H, Hirai T, Maenaka K, Techangamsuwan S, Lan NT. Nectin4 is an epithelial cell receptor for canine distemper virus and involved in neurovirulence. J Virol. 2012;86(18):10207.

3. Zhao N, Li M, Luo J, Wang S, Liu S, Wang S, Lyu W, Chen L, Su W, Ding H. Impacts of canine distemper virus infection on the giant panda population from the perspective of gut microbiota. Sci Rep. 2017;7:39954.

4. Na F, Yicong Y, Tiecheng W, Wilker P, Jianzhong W, Yuanguo L, Zhe S, Yuwei G, Xianzhu X. Fatal canine distemper virus infection of giant pandas in China. Scientific Report [J]. 2016;6:27518-7.

5. Beineke A, Puff C, Seehusen F, Baumgartner W. Pathogenesis and immunopathology of systemic and nervous canine distemper. Vet Immunol Immunopathol [J]. 2009;127:1):1-18.

6. Wei Q, Zheng Y, Shoufeng Z, Quanshui F, Hua L, Fuqiang Z, Wang W, Liao $\mathrm{G}$, Rongliang H. Canine distemper outbreak in rhesus monkeys, China. Emerging Infect Dis [J]. 2011;17(8):1541-3.

7. Roelke-Parker ME, Munson L, Packer C, Kock R, Cleaveland S, Carpenter M, O'Brien SJ, Pospischil A, Hofmann-Lehmann R, Lutz H. A canine distemper virus epidemic in Serengeti lions (Panthera leo). Nature. 1996;379(6564):441-5.

8. Ekkommonen C, Sihvonen L, Pekkanen K, Rikula U, Nuotio L. Outbreak off canine distemper in vaccinated dogs in Finland. Vet Rec. 1997;141(15):380-3.

9. Williams ES, Thome ET, Appel MJG, Belitsky DW. Canine distemper in black-footed ferrets (mustela nigripes) from Wyoming. J Wild Dis. 1988;24(3):385-98.

10. Zhaozeng S, Li A, Huahu Y, Yansheng S, Hu Zhongming LZ. Natural infection with canine distemper virus in hand-feeding rhesus monkeys in China. Veterinary Microbiology [J]. 2010;141(3-4):374-8.

11. Sakai K, Nagata N, Ami Y, Seki F, Suzaki Y, Iwata-Yoshikawa N, Suzuki T, Fukushi S, Mizutani T, Yoshikawa T, et al. Lethal canine distemper virus outbreak in cynomolgus monkeys in Japan in 2008. J Virol. 2013;87(2):1105-14.

12. Loots AK, Mitchell E, Dalton DL, Kotzé A, Venter EH. Advances in canine distemper virus (CDV) pathogenesis research: a wildlife perspective. J Gen Virol. 2016;98:3.

13. Seimon TA, Miquelle DG, Chang TY, Newton AL, Korotkova I, Ivanchuk G, Lyubchenko E, Tupikov A, Slabe E, Mcaloose D: Canine distemper virus: an emerging disease in wild endangered Amur tigers (Panthera tigris altaica). Mbio 2013, 4(4):16-16.

14. Gordon CH, Banyard AC, Hussein A, Laurenson MK, Malcolm JR, Marino J, Regassa F, Stewart AM, Fooks AR, Sillero-Zubiri C. Canine Distemper in Endangered Ethiopian Wolves. Emerging Infectious Diseases []]. 2015;21(5):824-32.

15. Hvistendahl M. Endangered species. Captive pandas succumb to killer virus. Science. 2015;347(6223):700-1.

16. Blixenkrone-Møller M. Detection of intracellular canine distemper virus antigen in mink inoculated with an attenuated or a virulent strain of canine distemper virus. Am J Vet Res. 1989;50(9):1616.

17. Barrett T. Morbillivirus infections, with special emphasis on morbilliviruses of carnivores. Vet Microbiol. 1999;69(1-2):3.

18. Furuta Y, Gowen BB, Takahashi K, Shiraki K, Smee DF, Barnard DL. Favipiravir (T-705), a novel viral RNA polymerase inhibitor. Antivir Res. 2013;100(2):446-54. 
19. Mendenhall M, Russell A, Juelich T, Messina EL, Smee DF, Freiberg AN, Holbrook MR, Furuta Y, Torre JCDL, Nunberg JH. T-705 (Favipiravir) inhibition of arenavirus replication in cell culture. Antimicrob Agents Chemother. 2011;55(2):782

20. Gowen BB, Wong MH, Jung KH, Sanders AB, Mendenhall M, Bailey KW, Furuta $Y$, Sidwell RW: In vitro and in vivo activities of T-705 against arenavirus and bunyavirus infections. Antivir Res 2007, 74(3):A44-A44.

21. Hideki T, Aiko F, Shuetsu F, Satoshi T, Tomoki Y, Naoko IY, Yuko S, Tadaki S, Noriyo N, Hideki H. Efficacy of T-705 (Favipiravir) in the treatment of infections with lethal severe fever with thrombocytopenia syndrome virus. Msphere. 2016;1(1).

22. Julander JG, Shafer K, Smee DF. Activity of T-705 in a hamster model of yellow fever virus infection in comparison with that of a chemically related compound, T-1106. Antimicrob Agents Chemother. 2009;53(1):202.

23. Julander JG, Smee DF, Morrey JD, Furuta Y. Effect of T-705 treatment on western equine encephalitis in a mouse model. Antivir Res. 2009;82(3):169-71.

24. Oestereich L, Lüdtke A, Wurr S, Rieger T, Muñoz-Fontela C, Günther S. Successful treatment of advanced Ebola virus infection with T-705 (favipiravir) in a small animal model. Antivir Res. 2014;105(1):17-21.

25. Rocha-Pereira J, Jochmans D, Dallmeier K, Leyssen P, Nascimento MSJ, Neyts J. Favipiravir (T-705) inhibits in vitro norovirus replication. Biochem Biophys Res Commun. 2012;424(4):777-80.

26. Jochmans D, Van NS, Smits SL, Neyts J, Fouchier RA, Bg VDH. Antiviral activity of Favipiravir (T-705) against a broad range of paramyxoviruses in vitro and against human Metapneumovirus in hamsters. Antimicrob Agents Chemother. 2016;60(8):4620.

27. Carvalho OV, Botelho CV, Ferreira CG, Scherer PO, Soaresmartins JA, Almeida MR, Silva JA. Immunopathogenic and neurological mechanisms of canine distemper virus. Adv Virol. 2012;2012(2):163860.

28. Sidhu MS, Menonna JP, Cook SD, Dowling PC, Udem SA. Canine distemper virus $L$ gene: sequence and comparison with related viruses. Virology. 1993;193(1):50-65.

29. Hartley WJ. A post vaccinal inclusion body encephalitis in dogs. Vet Pathol. 1974;11(4):301-12.

30. Appel MJ, Harris W. Antibody titers in domestic ferret jills and their kits to canine distemper virus vaccine. J Am Vet Med Assoc. 1988;193(3):332.

31. Stephensen CB, Welter J, Thaker SR, Taylor J, Tartaglia J, Paoletti E. Canine distemper virus (CDV) infection of ferrets as a model for testing morbillivirus vaccine strategies: NYVAC- and ALVAC-based CDV recombinants protect against symptomatic infection. J Virol. 1997;71(2):1506-13.

32. Buczkowski H, Muniraju M, Parida S, Banyard AC. Morbillivirus vaccines: recent successes and future hopes. Vaccine [J]. 2014;32(26):3155-61.

33. Carvalho OV, Botelho CV, Ferreira CG, Ferreira HC, Santos MR, Diaz MA, Oliveira TT, Soaresmartins JA, Almeida MR Jr, Silva A Jr. In vitro inhibition of canine distemper virus by flavonoids and phenolic acids: implications of structural differences for antiviral design. Res Vet Sci. 2013;95(2):717-24.

34. Lanave G, Cavalli A, Martella V, Fontana T, Losappio R, Tempesta M, Decaro N, Buonavoglia D, Camero M. Ribavirin and boceprevir are able to reduce canine distemper virus growth in vitro. J Virol Methods. 2017;248:JVI.00521-00517.

35. Wu ZM, Yu ZJ, Cui ZQ, Peng LY, Li HR, Zhang CL, Shen HQ, Yi PF, Fu BD. In vitro antiviral efficacy of caffeic acid against canine distemper virus. Microb Pathog. 2017;110.

36. González-Búrquez MJ, González-Díaz FR, García-Tovar CG, Carrillo-Miranda L, Soto-Zárate Cl, Canales-Martínez MM, Penieres-Carrillo JG, Crúz-Sánchez TA, Fonseca-Coronado S. Comparison betweenIn vitro antiviral effect of Mexican Propolis and three commercial flavonoids against canine distemper virus. Evidence-Based Complementray Altern Med. 2018;2018(2018-8-6):2018.

37. Krumm SA, Yan D, Hovingh ES, Evers TJ, Enkirch T, Reddy GP, Sun A, Saindane MT, Arrendale RF, Painter G. Orally available small-molecule polymerase inhibitor cures a lethal morbillivirus infection. Sci Transl Med. 2014;6(232):232ra252.

38. Bi Z, Xia X, Wang Y, Mei Y. Development and characterization of neutralizing monoclonal antibodies against canine distemper virus hemagglutinin protein. Microbiol Immunol. 2015;59(4):202-8.

39. Yi L, Cheng S. A monoclonal antibody against truncated $\mathrm{N}$ protein (aa 277-471) of canine distemper virus. Monoclonal Antibodies Immunodiagnosis Immunother. 2014;33(1):52-6.

40. Morrey JD, Taro BS, Siddharthan V, Wang H, Smee DF, Christensen AJ, Furuta Y. Efficacy of orally administered T-705 pyrazine analog on lethal West Nile virus infection in rodents. Antivir Res. 2008;80(3):377-9.
41. Furuta Y, Takahashi K, Shiraki K, Sakamoto K, Smee DF, Barnard DL, Gowen BB, Julander JG, Morrey JD. T-705 (favipiravir) and related compounds: novel broadspectrum inhibitors of RNA viral infections. Antivir Res. 2009;82(3):95-102.

42. Cai L, Sun $Y$, Song $Y, X u L$, Bei Z, Zhang D, Dou Y, Wang H. Viral polymerase inhibitors T-705 and T-1105 are potential inhibitors of Zika virus replication. Arch Virol. 2017;162(9):2847-53.

43. Vandevelde M, Zurbriggen A. The neurobiology of canine distemper virus infection. Vet Microbiol. 1995;44(2-4):271.

44. Vandevelde M, Zurbriggen A. Demyelination in canine distemper virus infection: a review. Acta Neuropathol. 2005;109(1):56-68.

45. Krakowka S. Mechanisms of in vitro immunosuppression in canine distemper virus infection. J Clin Lab Immunol. 1982;8(3):187.

46. Kiso M, Takahashi K, Sakai-Tagawa Y, Shinya K, Sakabe S, Le QM, Ozawa M, Furuta Y, Kawaoka Y. T-705 (favipiravir) activity against lethal H5N1 influenza a viruses. Proc Natl Acad Sci U S A. 2010;107(2):882-7.

47. Furuta Y, Takahashi K, Kuno-Maekawa M, Sangawa H, Uehara S, Kozaki K, Nomura N, Egawa H, Shiraki K. Mechanism of action of T-705 against influenza virus. Antimicrob Agents Chemother. 2005;49(3):981-6.

48. Zhao J, Shi N, Sun Y, Martella V, Nikolin V, Zhu C, Zhang H, Hu B, Bai X, Yan X. Pathogenesis of canine distemper virus in experimentally infected raccoon dogs, foxes, and minks. Antivir Res. 2015;122:1-11.

\section{Publisher's Note}

Springer Nature remains neutral with regard to jurisdictional claims in published maps and institutional affiliations.

Ready to submit your research? Choose BMC and benefit from:

- fast, convenient online submission

- thorough peer review by experienced researchers in your field

- rapid publication on acceptance

- support for research data, including large and complex data types

- gold Open Access which fosters wider collaboration and increased citations

- maximum visibility for your research: over $100 \mathrm{M}$ website views per year

At BMC, research is always in progress.

Learn more biomedcentral.com/submissions 